\title{
Research Article: Aspiration of students attending agriculture as vocational subject in higher secondary school in Amravati
}

\section{B.P. Bind, S.U. Mokhale, N.N. Dhote and S.M. Sarap}

Article Chronicle: Received : 02.05.2018;

Revised : 03.06.2018; Accepted : 17.06.2018

\section{KEY WoRds:}

Aspiration,

Economical aspiration, Educational aspiration, Higher Secondary School, Students, Vocational Subject

Author for correspondence :

\section{S.U. Mokhale}

Department of

Extension Education,

Shri Shivaji Agriculture

College, Amravati (M.S.)

India

Email : shekharmokhale $17 @$ gmail.com

See end of the article for authors' affiliations
SUMMARY : The present study on aspiration of higher secondary school students was conducted in the year 2016-2017 in Amravati district. The study revealed that nearly high number (55\%) of respondents were male, majority of the respondents $(73.75 \%)$ secured distinction category of academic performance, majority of the students ( $31.25 \%$ ) belonged to the marginal land holding, majority of the respondent's father more than half of respondents $(62.5 \%)$ fathers were educated medium category and more than half of the respondents $(73.75 \%)$ mother were educated medium category, more than half of the respondents (55\%) fathers had farming as occupation and respondents family $(32.5 \%)$ had low level of income in the range of (upto 50,000). The study revealed that the variables i.e. the independent variables namely family education and parental occupation observed positive and significant at $0.05 \%$ level of probability. Whereas the independent variables namely academic performance, land holding, and family income were positive and significant to the aspiration at $0.01 \%$ level of probability. The independent variables namely gender of students were non- significant to the aspiration.

How to cite this article : Bind, B.P., Mokhale, S.U., Dhote, N.N. and Sarap, S.M. (2018). Aspiration of students attending agriculture as vocational subject in higher secondary school in Amravati. Agric. Update, 13(3): 261-264; DOI : 10.15740/HAS/AU/13.3/261-264. Copyright@2018: Hind Agri-Horticultural Society. 